\title{
SEXUAL BEHAVIOUR AND KNOWLEDGE OF ADOLESCENT MALES IN THE MOLOPO REGIC
BOPHUTHATSWANA
}

\author{
Mary Kau
}

\begin{abstract}
Teenage pregnancy is one of the many public health problems facing the community in Bophuthatswane and neighbouring areas. Health professionals have attempted to address the problem yet little has been done to determine the role of the adolescent male in the prevention of this community problem. This study addresses the male adolescent's sexual behaviour, his attitude towards contraception, contraceptive use and premarital pregnancy. The study revealed that most of the respondents commenced sexual practices at about 12 years of age. These young men believed that girls should prove their fertility before marriage, although they viewed contraception as a joint responsibility between the two partners. The respondents were found to have a positive attitude towards contraception and contraceptive use, yet when they were asked what method of contraception they used since they were sexually active, only $24,5 \%$ reported use of a condom. Ignorance about reproduction and the effects of contraceptives was confirmed when $48 \%$ of the respondents indicated that they were unaware of the fact that pregnancy could result from first coitus, and they also believed that oral contraceptives had dangerous side effects. The study further revealed that parents did not discuss teenage pregnancy and contraception with their children, instead this subject was discussed among friends at school. Respondents expressed fear when asked why the subject was never discussed with parents, some actually stated that their parents would 'flog' them if they initiated the subject on sex and related matters. The urgent need for formalised sex education in Bophuthatswana was expressed by $77 \%$ of the respondents.
\end{abstract}

\section{INTRODUCTION}

Unplanned and unwanted pregnancy continues to be a disturbing and complex social problem facing the community in the Molopo Region of Bophuthatswana. According to records of one of the clinics serving a population of 9,975 between January 1985 and December 1987, 2464 clients were treated at the antenatal clinic of this centre and of these $17.5 \%$ were teenagers between 13 and 18 years. Senderowitz and Paxman (1985) concur with the above findings. In their worldwide study of adolescent pregnancy it was found that out-of wedlock births among adolescents continue to cause concem both in developing and First World countries. Could one then ask the question whether lack of knowledge on reproduction and sexuality in the sexually active male adolescent is responsible for the teenage pregnancy rate in the region under study? It also was assumed that perhaps lack of responsibility in the use of contraceptives by the male teenager could aggravate the problem of teenage pregnancy.

\section{OBJECTIVES OF THE STUDY}

The survey was conducted to determine the male adolescent's sexual behaviour, his knowledge of contraception, his contraceptive use and attitude towards teenage pregnancy and contraceptive use.

\section{BACKGROUND INFORMATION RELATED TO TEENAGE PREGNANCY AMONG THE BOTSWANA}

According to traditional custom among the Botswana, sexual practice should be postponed until after marriage (Lekgetha 1985). This practice was found among most Black Tribes in Southem Africa in the past. The traditional Zulus according to Vilakazi (1965:33) "had adequate social institutions and practice for coping with the sexual needs of the unmarried youth." For instance in the past, long before the traditional Zulu boy began to think about marriage, a great deal about sex was taught to him by the older boys. This was reinforced by the elders of the tribe at the initiation school where in addition to circumcision, instruction on sexual behaviour, marriage and all that it entails was taught.

Ashton (1952) states that among the Basotho, premarital sex was prohibited, and as a result young men and young girls remained innocent until after marriage.
Teenage pregnancy was considered a disgrace to the parents of the girl, a bad omen and a disgrace to the entire clan and age set of the victim. (Schapera, 1933: 63).

In contrast, over the last several decades, characterised by change in social structure, and gradual disintegration and collapse of traditional values and practices and with boys and girls mingling freely, Craig \& Richter - Strydom (1983:454) found that all social control measures used in the past were replaced by "coitus and a great deal of ignorance about sex among teenagers." Mothers were found to lack the skill to impart sex education to their daughters and negative threats such as "stay away from boys for they will bring shame on you" were commonly used by mothers to their teenage daughters.

\section{CONTRACEPTIVES AND MALE TEENAGERS}

In a study conducted by the author in 1987 (Kau 1988) 210 school girls in the Molopo Region of Bophuthatswana reported that they received information on contraceptives from a variety of sources. Thirty three percent reported they had received such information from friends, $11 \%$ from the nurse, $10 \%$ from the mother and $5 \%$ from the school teacher. None of the respondents mentioned the boyfriend or the father. These findings are in agreement with those of Bedger (1980: 87) who reported that "the illegitimate father's attitude towards birth control may influence the decision to use or not to use contraceptives." In this study of teenage pregnancy in Illinois, $63 \%$ of the girls interviewed reported that their boyfriends would not allow them to use contraceptives. Twelve percent reported that their partners felt it was the woman's responsibility to see that she was protected against pregnancy. Bedger's study revealed that teenage males, in general, did not encourage contraception or even initiate it in their discussion with their sexual partners. These findings concur with those of Craig \& Richter-Strydom (1983) who found that sexually active males interviewed in Zululand, displayed a negative attitude towards the use of contraceptives, yet once the partner got pregnant she was blamed for the negligence. Thomson \& Spanier 
(1979) found that males, in general, are not motivated towards the prevention of pregnancy.

The thrust of this study therefore was to determine the sexual behaviour of Black adolescent males, their attitude towards teenage pregnancy and contraception. Of utmost importance was the search for correct postulates to the unresolved problem of teenage pregnancy and the discovery of ways to involve adolescent males in contraceptive use.

\section{THE SCOPE OF THE SURVEY AND METHODOLOGY}

The study was conducted from September 1988 to May 1990 in the Molopo Region of Bophuthatswana. Two hundred (200) male pupils from five high schools and two middle schools were interviewed. Three of the schools were in the rural areas and the rest in the urban area.

\section{THE RESEARCH DESIGN}

A non-experimental design was used in which information on the variables sexual activity and behaviour as it exists in the Molopo Region was obtained. Information on the characteristics of the sample, the attitude of the respondents towards contraception, contraceptive use and teenage pregnancy was obtained by using a questionnaire.

\section{SAMPLING}

Subjects who participated in the study were Black adolescent males in the age group 1318 years enrolled in 7 schools. The total target population was 2000 at the time of the study. Of these 992 came from the urban area and 1008 were rural. To select a representative sample $10 \%$ of the total target population was calculted; and using random numbers 200 pupils were selected, each of which had an equal chance of forming the sample.

\section{PILOT STUDY}

The questionnaire was written in English which is the second language of the subjects of this study. A pilot study was conducted to determine whether subjects would experience any difficult in answering the questions put to them. This study involved 50 pupils from different schools and the test group was excluded from the main study. The results of the pilot study revealed no language problems among the subjects.

\section{DATA GATHERING INSTRUMENT}

The questionnaire consisted of 73 questions comprising response categories with a single dimension, closed-ended unordered questions for which response categories were provided, and open-ended questions for which respondents had to provide an answer. The questionnaires were distributed to the principals of the seven schools who distributed them to the respondents according to the list in the respective schools. In one school, due to the school policy regarding sex education, the principal refused to distribute the questionnaire to the pupils for completion. The investigator however, was allowed to transport the respondents to another venue where questionnaires were completed. Confidentiality was maintained throughout the study.

The questionnaire tapped information relating to demography, the respondent's sexual behaviour, knowledge of contraception and contraceptive use, attitude towards teenage pregnancy, parental involvement with regard to education and the need for the inclusion of sex education in the school syllabi. There was $100 \%$ return of questionnaires.

\section{TREATMENT OF DATA AND RESULTS}

Data were transferred from the questionnaire onto coding sheets and processed at the University of Bophuthatswana's Computation Centre. Analysis was carried out using the South African Soft Ware Program (SAS)

TABLE 1

Age of the Semple Populotion

\begin{tabular}{|c|c|c|}
\hline AGE & FREQUENCY & PEFCENTAOE \\
\hline 13 & 18 & 8.0 \\
\hline 14 & 27 & 13.5 \\
\hline 15 & 36 & 18.0 \\
\hline 16 & 46 & 24.0 \\
\hline 17 & 28 & 14.0 \\
\hline 18 & 45 & 22.5 \\
\hline TOTAL & 200 & 100.0 \\
\hline
\end{tabular}

Most of the respondents were aged 15-18 years $(78.5 \%)$. The respondents religious affiliation was determined and $76(38 \%)$ reported belonging to the Roman Catholic Church and $39.5 \%$ to other denominations. More than half $(52.5 \%)$ of the subjects reported that, "they go to church every Sunday without having to be reminded by parents." The educational standard of each parent was analysed to establish the educational background of respondents, and $57.5 \%$ of the students interviewed reported that neither of their parents ever attended high school. The respondent's attitude towards teenage pregnancy was cross tabulated with the father's standard of education, and no significant relationship was found (Chi-square value $=2.197$ with 4 Degrees of Freedom p. $>7$ ). The researcher concluded that the parent's educational level did not influence the offspring's attitude towards the prevention of teenage pregnancy. To the question "Have your parents discussed the topic of teenage pregnancy with you?" $63 \%$ reported that this was never discussed with them by their parents.
Respondents were asked if they had had sexual intercourse with a girl prior to the interview.

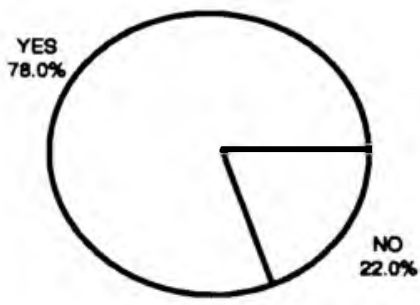

TOTAL NUMBER OF RESPONSES: 200

FIGURE 1

Determinetion of whether reepondente had hed eexual intercourse with e girl

The above figure indicates that $78 \%$ of the respondents at the time of the interview had slept with a girl. In other words they were sexually active, yet no formalized sex education is offered to the youth in Bophuthatswana. These findings confirm those of

Delcampo, Sporakowski \& Delcampo (1976: 180-186) who reported that "young men and women experiment with premarital sex and desire information about contraception."

Subjects were asked their age when they had sexual relations for the first time.

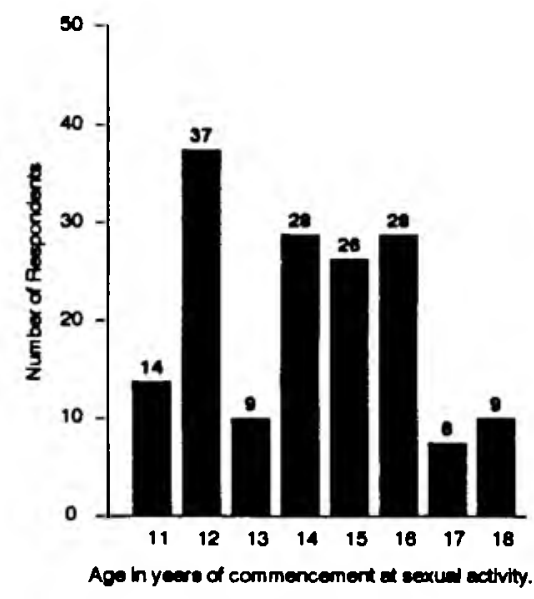

TOTAL RESPONDENTS: 200

FIGURE 2

Age at which

eexual ectivity commenced

Figure 2 shows the critical age at which repsondents in this study commenced sexual activity and a trimodal distribution of 12,14 and 16 years is seen. The findings concur with those of Finkel \& Finkel (1981) in their study of the sexual behaviour of boys in Texas in which the mean age of commencement of sexual behaviour was 12.3 years

The relationship that existed between the respondent and the girl at the time of first coitus was computed, and the diagram below revealed that $43.0 \%$ of the respondents had their first sex experience with a girl encountered ca- 
sually. This suggests that casual sex among youth is practiced commonly in the Molopo Region.

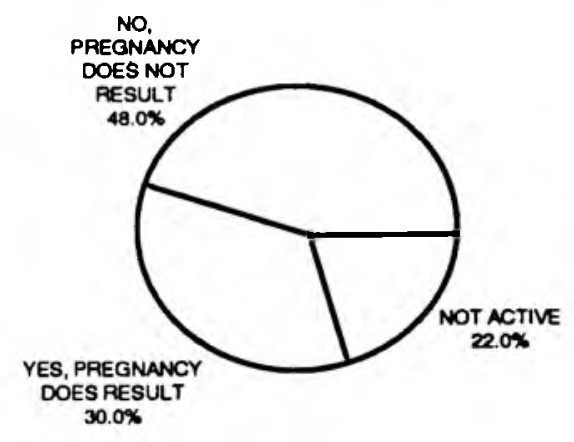

TOTAL NUMBER OF RESPONSES: 200

FIGURE 3

Indication of respondents knowledge regarding pregnancy reaulting from the firet sexual encountor

Forty eight percent (48\%) or almost half of the sample did not know that pregnancy could take place at first intercourse.

Venues for the place of first sexual encounter are shown in Table 2. In most cases of use of one of the partner's homes, the parents were absent at the time.

Although 55,5\% of the respondents reported sexual activity, they also reported not to have

TABLE 2

Venue of first sexual encounter

\begin{tabular}{|l|c|c|}
\hline \multicolumn{1}{|c|}{ VENUE } & $\begin{array}{c}\text { NUMBERs } \\
\text { N=200 }\end{array}$ & $\begin{array}{c}\text { PEACENTAGE } \\
\text { Of TOTAL }\end{array}$ \\
\hline In his home & 50 & 25,0 \\
\hline In her home & 51 & 25,5 \\
\hline At a triend's pleco & 38 & 18,0 \\
\hline Other & 17 & 8,5 \\
\hline N/A & 44 & 22,0 \\
\hline Total & 200 & 100,0 \\
\hline
\end{tabular}

TABLE 3

Indication of whother contraception was discuseed with the partner at first Intercouree

\begin{tabular}{|l|c|c|}
\hline $\begin{array}{c}\text { CONTRACEPTION } \\
\text { DISCUSSED }\end{array}$ & $\begin{array}{c}\text { NUMBERS } \\
\text { N=150 }\end{array}$ & PERCENTAQE \\
\hline Yes & 46 & 23,0 \\
\hline No & 110 & 55,5 \\
\hline Total & 156 & 76,5 \\
\hline
\end{tabular}

discussed contraception with their partners. Reasons for not discussing contraception were elicited and $32 \%$ cited ignorance about contraceptives and their effects, $7.5 \%$ reported that they were too shy to talk about the subject to the partner. Five percent stated that they did not care, and that what they wanted was sex with the girl; the rest stated that the girls were easy targets.
TOTAL NUMBEROF RESPONSES: 200

FIGURE 4

Indicatlon of respondents opinion regarding the etetement "Promartial Sox ia Wrong"

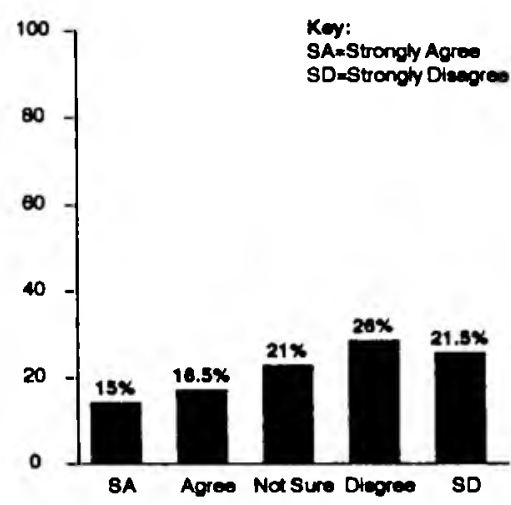

Forty seven percent of the respondents disagreed that sex before marriage was wrong; to these respondents premarital sex was acoeptable and was a practice considered normal and necessary.

Asked if parents ever discussed contraception with them, of the 200 respondents, $63 \%$ stated that such a subject was never discussed. Fiftyseven percent of the boys said that they had never taken the initiative in discussing contraception with their parents, and some of these reported that their parents would 'wallop' them for mentioning such a topic.

The attitude of the respondents towards teenage pregnancy was determined and in this study, respondents believed that a girl must prove her fertility before marriage. Sixty four percent (64\%) of the respondents agreed that a girl must have a baby before marriage. This the researcher found as a complete shift from the traditional attitude of the Botswana towards premarital pregnancy which was frowned upon. In fact, according to Phillips (1953) the illegitimate child was killed, and the mother was subjected to punishment, including being given away to an old man as a free gift for a wife without "lobola" (dowry).

Respondents attitudes towards sex education were determined and it was clear that it was thought desirable that parents and the school should both offer this type of education.

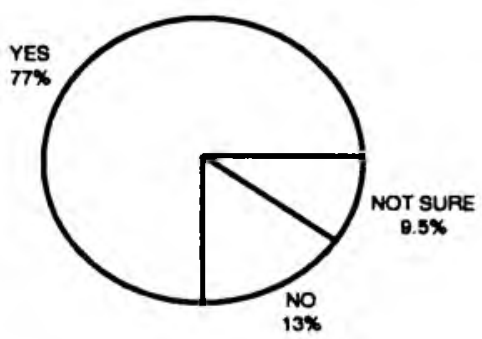

TOTAL NUMBEROF RESPONSES: 200.

FIGURE 5

INDICATION OF THE RESPONDENTS' ATITUDE TOWARDS RECENING SEX EDUCATION FROM PARENTS AND THE SCHOOL
The need for organized sex education (iormalised sex education) was determined, $44 \%$ of the respondents strongly agreed that this education was long overdue, $38 \%$ agreed and only $6 \%$ disagreed with the notion.

\section{DISCUSSION}

Following the analysis of data, the following comments are made with regard to the sexual behaviour, attitude towards contraception, contraceptive use and premarital pregnancy of the youth in the Molopo Region of the Republic of Bophuthatswana.

The questionnaire revealed that the majority of the respondents were between 15 and 18 years of age, and were attending schools in standards ranging from 5 to 9 . The male adolescents in the Molopo Region were found to be sexually active and believed that girls must prove their fertility before marriage. Of the $78 \%$ who reported to be sexually active, only $24.5 \%$ used a condom. Respondents in this study therefore were sexually active yet did not take precautions to prevent the oocurence of pregnancy.

Casual sex was found to be the order of the day and the female partner was usually "a girl that was just met" and was not the respondent's girlfriend.

Ages 12 to 14 seemed to be the critical period during which adolescents in this study initiated sexual activity which suggests that in the event of educational intervention this is the critical period on which to concentrate.

Respondents were ignorant about contraceptives and their effects. This was shown by $62,5 \%$ of the responses revealing that parents never discussed the topic of contraception with their children. What was more salient was the fact that $23.5 \%$ of the respondents reported that even if they wanted to discuss the subject, their parents would not discuss it with them. Ignorance about contraceptives was further revealed when respondents associated a girl who became pregnant with ill-luck or unter stupidity.

With regard to contraceptive use, it was interesting to find that $40 \%$ of the respondents considered the condom to be the most effective yet only $24.5 \%$ reported using it, and $32.5 \%$ said they used 'nothing' during coitus.

All respondents agreed that it was a good thing to prevent the occurence of pregnancy before marriage, yet despite this positive attitude, in practice the majority seem to shy away from the responsibility of personally using contraceptives.

Formalised sex education is not offered in schools in Bophuthatswana and respondents in this study have expressed clearly the need for this type of education. Seventy seven (77\%) percent of boys expressed the need for school as well as parental involvement in this type of education. 


\section{RECOMMENDATIONS}

The findings of this study indicate that formalized programmes to teach parents to communicate effectively with their children about human sexuality should be introduced in Bophuthatswana. If these programmes create problems because of cultural barriers, then the school is the only altemative to offer sex education to the youth, and school nurses could give this type of education until such time that the Department of Education has incorporated sex education into the school curriculum.

This study should be repeated in future using a larger sample drawn beyond the borders of Bophuthatswana so that results could be generalized to the whole of Southem Africa.

Youth Centres concentrating on adolescent sex problems should be introduced in Bophuthatswana. At such centres information on human sexuality and contraception could be imparted to those adolescents who are sexually active. Supervised peer group teaching is highly recommended. This need was also revealed in Kau's (1988) findings when a study of teenage girls was conducted.

\section{CONCLUSION}

From the literature reviewed it is clear that a definite shift has occurred from the traditional beliefs regarding the preservation of virginity until after marriage, to a permissive attitude towards sexual activity which is characterized by casual sex with multiple partners commencing at about age 12. Respondents in the present study reported that girls should prove their fertility before marriage, a practice that is completely contrary to the traditional beliefs and practices of the Botswana.

With the gradual disappearance of the initiation school, whose main purpose was to impart knowledge on human sexuality, an alternative has to be found to perform this task. It is therefore hoped that through the findings of this study, the Department of Education in Bophuthatswana will consider the promotion of a national policy supporting the introduction of sex education which will incorporate contraceptive education and responsible future parenthood for the adolescent. The implementation of sex education will place students in a better position to understand themselves and be better able to make decisions regarding their sexual behaviour.

\section{REFERENCES}

ASHTON, H. 1952 The Basuto. London: Oxford University Press.

BEDGER, J.E. 1980. Teenage pregnancy research related to clients and services. Illinois: Thomas Publishers.

CRAIG, A.P. \& RICHTER-STRYDOM, L.M. 1983. Unplanned pregnancies among urban Zulu school girls. South African Medical Journal Vol 63,12,452-55.

DELCAMPO, R.L., SPORAKOWSKI, M.J., DELCAMPO, D.S., 1976. Premarital Sexual Permisiveness and Contraceptive Knowledge: A biracial comparison of college students, Journal of Sex Research, Vol. 12, No.3, 180-186.

FINKEL, M.L. \& FINKEL, D.J.1975 \& 1981. Sexual and contraceptive knowledge, attitudes and behaviour of male adolescents. Family Planning Perspectives, Vol. 7, No. 6. November/December, 257-260.

KAU, M. Sexual Behaviour and Contraceptive use by Teenagers age $13-18$ years who reside in the Molopo Region of Bophuthatswana. International Quarterly of Community Health Education Vol. 9 (1) 1988 (USA).
LEKGETHA, A.N. 1985. People and Family Planning. A paper presented on a health day at Mmabatho.

PHILLIPS, A. 1953. Survey of African Marriage and Family Life. London: Oxford University Press.

SENDEROWITZ J. AND PAXMAN J.N., 1985, Adolecent Fertility: world wide concern. Population Bulletin, Vol. 40, No. 2, 1-5.

SCHAPERA, I. 1933. Premarital pregnancy and native opinion. A note on Social change. Africa. Vol. VI No. 159-89.

THOMSON, L SPANIER, G.S. 1979. Influence of parents, peers and partners on the contraceptive use of College men and women. Journal of Marriage and Family. August 483-492.

VILAKAZI, S., 1965. Zulu Transformation: A study of the dynamics of social change. Pietermaritzhurg, University of Natal Press.

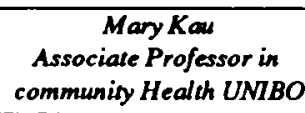

